University of Nebraska - Lincoln

DigitalCommons@University of Nebraska - Lincoln

Uniformed Services University of the Health

Sciences

U.S. Department of Defense

2008

\title{
Association Between Alcohol Consumption and Both Osteoporotic Fracture and Bone Density
}

\author{
Karina M. Berg \\ Departments of Medicine \\ Hillary V. Kunins \\ Departments of Medicine \\ Jeffrey L. Jackson \\ Uniformed Services University \\ Shadi Nahvi \\ Departments of Medicine \\ Amina Chaudhry \\ Johns Hopkins University \\ See next page for additional authors
}

Follow this and additional works at: https://digitalcommons.unl.edu/usuhs

Part of the Medicine and Health Sciences Commons

Berg, Karina M.; Kunins, Hillary V.; Jackson, Jeffrey L.; Nahvi, Shadi; Chaudhry, Amina; Harris, Kenneth A. Jr.; Malik, Rubina; and Arnsten, Julia H., "Association Between Alcohol Consumption and Both Osteoporotic Fracture and Bone Density" (2008). Uniformed Services University of the Health Sciences. 11.

https://digitalcommons.unl.edu/usuhs/11

This Article is brought to you for free and open access by the U.S. Department of Defense at DigitalCommons@University of Nebraska - Lincoln. It has been accepted for inclusion in Uniformed Services University of the Health Sciences by an authorized administrator of DigitalCommons@University of Nebraska Lincoln. 


\section{Authors}

Karina M. Berg, Hillary V. Kunins, Jeffrey L. Jackson, Shadi Nahvi, Amina Chaudhry, Kenneth A. Harris Jr., Rubina Malik, and Julia H. Arnsten 


\title{
Association Between Alcohol Consumption and Both Osteoporotic Fracture and Bone Density
}

\author{
Karina M. Berg, MD, MS, ${ }^{a, c}$ Hillary V. Kunins, MD, MS, MPH, ${ }^{a, c}$ Jeffrey L. Jackson, MD, MPH, ${ }^{d}$ Shadi Nahvi, MD, ${ }^{a, c}$ \\ Amina Chaudhry, MD, MPH, ${ }^{e}$ Kenneth A. Harris, Jr, MD, PhD, ${ }^{a, c}$ Rubina Malik, MD, MS, ${ }^{a}$ Julia H. Arnsten, MD, MPH ${ }^{a, b, c}$ \\ ${ }^{a}$ Departments of Medicine, ${ }^{b}$ Epidemiology and Population Health, and ${ }^{c}$ Psychiatry and Behavioral Sciences, Albert Einstein College of \\ Medicine and Montefiore Medical Center, Bronx, NY; ' Uniformed Services University, Bethesda, Md; ${ }^{e} J o h n s$ Hopkins University, \\ Baltimore, $M d$.
}

\begin{abstract}
OBJECTIVE: Alcoholism is a risk factor for osteoporotic fractures and low bone density, but the effects of moderate alcohol consumption on bone are unknown. We performed a systematic review and metaanalysis to assess the associations between alcohol consumption and osteoporotic fractures, bone density and bone density loss over time, bone response to estrogen replacement, and bone remodeling.

METHODS: MEDLINE, Current Contents, PsychINFO, and Cochrane Libraries were searched for studies published before May 14, 2007. We assessed quality using the internal validity criteria of the US Preventive Services Task Force.

RESULTS: We pooled effect sizes for 2 specific outcomes (hip fracture and bone density) and synthesized data qualitatively for 4 outcomes (non-hip fracture, bone density loss over time, bone response to estrogen replacement, and bone remodeling). Compared with abstainers, persons consuming from more than 0.5 to 1.0 drinks per day had lower hip fracture risk (relative risk $=0.80$ [95\% confidence interval, 0.71-0.91]), and persons consuming more than 2 drinks per day had higher risk (relative risk $=1.39$ [95\% confidence interval, 1.08-1.79]). A linear relationship existed between femoral neck bone density and alcohol consumption. Because studies often combined moderate and heavier drinkers in a single category, we could not assess relative associations between alcohol consumption and bone density in moderate compared with heavy drinkers. CONCLUSION: Compared with abstainers and heavier drinkers, persons who consume 0.5 to 1.0 drink per day have a lower risk of hip fracture. Although available evidence suggests a favorable effect of alcohol consumption on bone density, a precise range of beneficial alcohol consumption cannot be determined. (C) 2008 Elsevier Inc. All rights reserved. • The American Journal of Medicine (2008) 121, 406-418
\end{abstract}

KEYWORDS: Alcohol; Bone mineral density; Hip fracture; Meta-analysis; Osteoporosis

This study was funded by the Program of Research Integrating Substance Use in Mainstream Healthcare with support from the Robert Wood Johnson Foundation, National Institute on Drug Abuse (NIDA), and National Institute on Alcohol Abuse and Alcoholism (co-directors A. T. McLellan, PhD, and B. J. Turner, MD, MSEd). Additional support was provided by grants K23 DA021087 from the NIDA and the National Institute of Mental Health and a Robert Wood Johnson Foundation Physician Faculty Scholar Award to Dr Berg; grants R25 DA14551 and R01 DA015302 from the NIDA to Dr Arnsten; and a Center for AIDS Research grant (P30 AI51519) to the Albert Einstein College of Medicine of Yeshiva University from the National Institutes of Health.

Requests for reprints should be addressed to Karina M. Berg, MD, MS, Montefiore Medical Center, Division of General Internal Medicine, 111 East 210th Street, Bronx, NY 10467.

E-mail address: kberg@montefiore.org
The prevalence of low bone density among men and women aged more than 50 years has been estimated at greater than 44 million. ${ }^{1}$ In this population, 1 in 2 women and 1 in 4 men develop osteoporotic fractures. ${ }^{2}$ In addition to unmodifiable risk factors such as age and sex, bone density is influenced by modifiable lifestyle factors, including alcohol consumption.

Chronic heavy alcohol consumption is widely considered a risk factor for osteoporotic fractures and low bone density. ${ }^{2}$ However, this relationship is based on small studies of men $^{3-7}$ and has not been established in women. ${ }^{8}$ In contrast, several studies have reported that moderate alcohol use may decrease fracture rates and increase bone density. ${ }^{9-18}$ In 2001 , a National Institutes of Health panel concluded that "alcoholism" is a cause of osteoporosis but that "consumption of alcoholic beverages" has an inconsistent effect on bone. ${ }^{19}$ 
We performed a systematic review and meta-analysis to assess the associations between alcohol consumption and osteoporotic hip and non-hip fractures, bone density and bone density loss over time, bone response to estrogen replacement, and bone remodeling. Our secondary aim was to examine whether the effect of alcohol on these outcomes is modified by sex.

\section{MATERIALS AND METHODS}

\section{Search Strategies}

On May 14, 2007, we searched all Ovid MEDLINE databases, the Cochrane Central Register of Controlled Trials, Current Contents Connect, and PsychINFO. We defined search terms for alcohol consumption and each outcome (Appendix), and limited the results to human subjects and English language. We then manually searched references of included studies and pertinent reviews.

\section{Study Selection}

Two reviewers independently assessed each citation using predefined criteria. Included studies had experimental, cohort, or case-control designs; included adults both exposed and not exposed to alcohol; and reported on at least 1 outcome. We excluded studies in which alcohol consumption and bone density were measured once at the same point in time to avoid invalid assumptions about temporal sequence. To examine osteoporotic fracture rate, we identified studies of low-impact fractures of the hip, wrist, forearm, or vertebra. To evaluate bone density, we sought prospective studies in which bone density was assessed by central dual energy x-ray absorptiometry and measured after alcohol exposure. Studies examining bone density loss over time required bone density measures at 2 points in time. To examine the outcome of bone response to estrogen, we identified studies reporting the effect of alcohol on osteoporotic fracture rates or bone density among postmenopausal women taking estrogen replacement therapy. For the final outcome, bone remodeling, we included studies examining markers of bone formation and resorption (Appendix). Abstract ratings between reviewers had 92\% agreement $(\kappa=0.73)$. Disagreements were resolved by discussion.

\section{Assessment of Study Quality}

We assessed study quality using the internal validity criteria of the US Preventive Services Task Force, ${ }^{20}$ assigning a rating of "good" when all criteria were met, "fair" when 1 or more criterion was partially met and the study contained no fatal flaws, and "poor" if 1 or more criterion was not met and a fatal flaw invalidated the results. Studies of poor quality were excluded.

For our systematic review, studies were rated "good" if alcohol consumption was reported as a rate (eg, "drinks per day") and reflected data from more than a single survey item (ie, from separate questions about consumption of beer, wine, or spirits). Studies that used a single survey item, or did not sufficiently explain their measures, were rated "fair." Studies that used imprecise definitions of alcohol consumption (eg, "ever," "daily," or "yes") were rated "poor." In addition, we rated studies on the timing of their measurement of alcohol consumption. Prospective studies were rated "good" if alcohol consumption was measured at multiple time points and "fair" if alcohol consumption was measured at baseline only.

Prospective studies were rated "good" if fractures were ascertained by more than 1 source of information (eg, self-report verified by hospital records or a sample of specific International Classification of Diseases codes validated by chart review) and "fair" if only 1 information source was used. Casecontrol studies were rated "good" if cases were established using hospital records and "fair" if they were established by other means.

For all studies, we developed a predefined set of potential confounders that included age, body mass index, smoking, dietary calcium, physical activity, and estrogen exposure. "Good" studies adjusted for all potential confounders, "fair" studies adjusted for some confounders, and "poor" studies adjusted for age only. Differences were discussed until agreement was reached. Quality ratings between reviewers had $85 \%$ agreement $(\kappa=0.67)$.

\section{Data Extraction}

The first author (KMB) and 1 other author met to extract quantitative data on the association between alcohol consumption and the outcome, and adjustment for potential confounders. For example, data extracted may include the odds of hip fracture among those who consumed more than 0.4 drinks per day compared with abstainers (odds ratio $=0.69 ; 95 \%$ confidence interval $[\mathrm{CI}], 0.53-0.90)$, after adjusting for age, body mass index, smoking, and estrogen therapy. ${ }^{21}$ One investigator was contacted by the first author to request numeric data that corresponded to a figure in the original study. ${ }^{22}$ Because studies reported alcohol consumption using numerous units of measurement, we converted alcohol consumption into drinks per day by estimating that each standard drink is equivalent to $14 \mathrm{~g}$ or 0.6 fluid oz of 


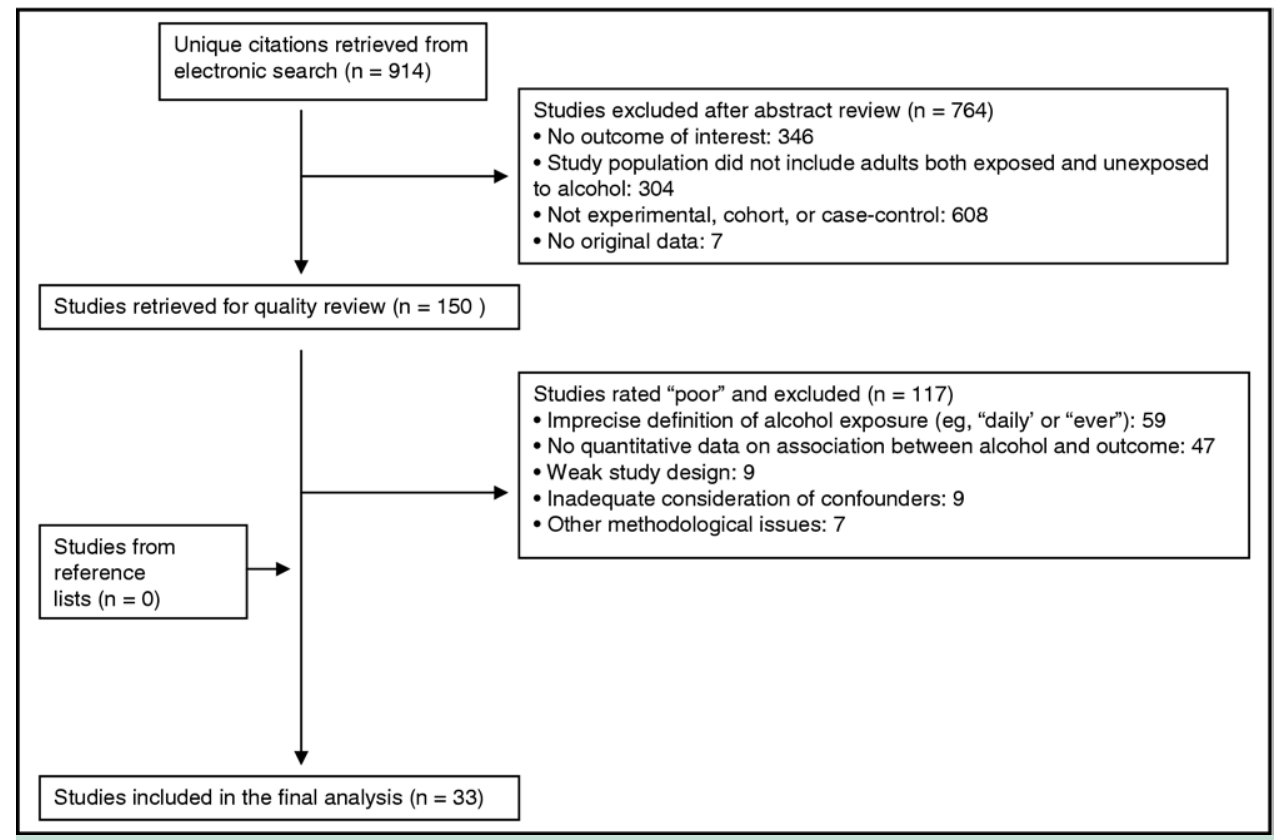

Figure 1 Study selection process. Studies may be excluded for multiple reasons.

pure alcohol, ${ }^{23}$ that there are $29 \mathrm{~kJ} / \mathrm{g}$ of alcohol, ${ }^{24}$ and that 1 unit of alcohol equals $8 \mathrm{~g}$ of pure alcohol. ${ }^{25}$

\section{Data Synthesis}

For pooled estimates of the effect of alcohol consumption on hip fracture incidence, we extracted relative risk (RR) data, created strata of alcohol use, and performed a doseresponse analysis using mean drinks per day when studies reported ranges of alcohol consumption. For the few studies that reported multiple categories of alcohol consumption within 1 defined strata, we "pooled first" using inverse variance weights. Given the rarity of events, RRs and odds ratios for hip fractures were considered equivalent. We combined fracture data by log transforming reported effects in each stratum and then pooled data with the random effects models. ${ }^{26}$ Sex-stratification of the analysis of alcohol consumption and hip fracture was not possible because only 1 study reported results by sex.

For bone density, we pooled data using a dose-response regression model with adjustment for clustering within studies using inverse variance as analytic weights. ${ }^{27}$ When necessary, we imputed variance using the method of Follman et al. ${ }^{28}$ For each outcome, when no upper limit was given for the highest category of alcohol consumption, we multiplied the reported limit by 1.5 , a method used in a similar metaanalysis. $^{29} \mathrm{We}$ were unable to perform a meta-analysis of bone density loss over time because of the disparate outcomes reported (eg, beta-coefficient for the effect of alcohol on bone density loss, annual rate of bone density loss, or percentage of bone density loss). The results were not significantly different for men and women for any outcome except bone density loss over time.
Heterogeneity was assessed using the $\mathrm{Q}$ and $\mathrm{I}^{2}$ statistics. Publication bias was assessed using the method of Egger et al. ${ }^{30}$ All meta-analyses were performed using STATA (STATA 9.2, College Station, Tex).

\section{RESULTS}

\section{Overview of the Evidence Base}

The results of our search strategy are illustrated in Figure 1. Most studies were conducted in white, European, or American adults aged more than 50 years. The results were commonly adjusted for age, body mass index, and smoking. However, few studies adjusted for dietary calcium, physical activity, or estrogen exposure.

\section{Alcohol Consumption and Hip Fracture Risk}

Eight of 13 studies that examined the association between alcohol consumption and risk of hip fracture were prospective cohort studies, ${ }^{33-40}$ and 5 were case-control studies $^{21,31,32,41,42}$ (Table 1). The case-control studies compared hospitalized cases with community controls, ${ }^{21,32,41}$ hospitalized controls, ${ }^{42}$ or both. ${ }^{31}$ Cases and controls were matched on age, sex, race or ethnicity, and residential area, $^{31,32}$ or geographic location only. ${ }^{21,41,42}$

Meta-analysis of the effect of alcohol consumption on hip fracture risk revealed a J-shaped relationship, which is illustrated in Figure 2. Compared with abstainers, we found a lower risk of hip fracture among persons consuming up to 0.5 drinks per day $(\mathrm{RR}=0.84$ [95\% CI, 0.70-1.01] $\mathrm{Q}=091$, $\mathrm{I}^{2}=0.00$, publication bias $P=.39$ ) and persons consuming from more than 0.5 to 1 drink per day $(\mathrm{RR}=0.80$ [95\% CI, $0.71-0.91] \mathrm{Q}=12.66, \mathrm{I}^{2}=0.21$, publication bias $P=.43$ ). Those consuming from more than 1 to 2 drinks per day did 
not differ from abstainers $(\mathrm{RR}=0.91$ [95\% CI, 0.76-1.09] $\mathrm{Q}=11.33, \mathrm{I}^{2}=0.24$, publication bias $P=.72$ ), and persons consuming more than 2 drinks per day had a higher risk of hip fracture $(\mathrm{RR}=1.39$ [95\% $\mathrm{CI}, 1.08-1.79] \mathrm{Q}=6.73$, $\mathrm{I}^{2}=0.24$, publication bias $P=.38$ ).

\section{Alcohol Consumption and Fracture of the Forearm, Wrist, or Vertebrae}

Of the 3 cohort studies that examined the effect of alcohol consumption on fracture of the forearm or wrist, 2 found no significant association ${ }^{40,43}$ and 1 found that women consuming 1.8 drinks or more per day had a higher risk of wrist fracture compared with abstainers (RR 1.38 [95\% CI, 1.091.74]). ${ }^{39}$ Two studies examined the relationship between alcohol consumption and risk of vertebral fracture; 1 found no significant association, ${ }^{40}$ and 1 found increased odds of fracture among men who consumed more than 0.3 drinks per day compared with abstainers (adjusted odds ratio 4.61 $[1.19-17.90]){ }^{44}$

\section{Alcohol Consumption and Bone Density}

Four cohort studies assessed the association between alcohol consumption and bone density (Table 2). ${ }^{12,13,16,33}$ Overall, there was a linear relationship between femoral neck bone density and alcohol consumption (Figure 3). Each drink per day was associated with an increase in femoral neck bone density of $0.045 \mathrm{~g} / \mathrm{cm}^{2}$ (95\% CI, $0.008-0.082$ $\left.\mathrm{g} / \mathrm{cm}^{2}, P=.01\right)$. A significant linear relationship also was found at the vertebral spine (data not shown).

\section{Alcohol Consumption and Bone Density Loss Over Time}

Four prospective cohort studies ${ }^{22,46-48}$ and 1 nested casecontrol study ${ }^{45}$ examined the association between alcohol consumption and bone density loss over time (Table 3). ${ }^{44-48}$ Two of the 3 studies that reported sex-stratified results found that the pattern of association between alcohol consumption and bone density loss was different in men and women. ${ }^{46,47}$

Bone Density Loss Over Time in Women. Four of the 5 studies that examined alcohol consumption and bone density loss over time in women found that women with greater alcohol consumption had lower bone density loss. ${ }^{21,45-48}$ Of the 5 studies, 2 studies measured alcohol consumption continuously and found a significant inverse linear association between alcohol consumption and bone density loss. ${ }^{45,46}$ Two other studies measured alcohol consumption categorically and found the lowest bone density loss among women with the greatest alcohol consumption (approximately 1-2 drinks per day). ${ }^{22,47}$ The final study found a U-shaped relationship between alcohol consumption and bone density loss, with the lowest bone density loss among women consuming 0.2 to 1.7 drinks per day and higher bone density loss among both abstainers and women consuming more than 1.7 drinks per day. ${ }^{48}$
Bone Density Loss Over Time in Men. Of the 3 studies that assessed alcohol consumption and bone density loss over time in men, 2 reported U-shaped relationships. ${ }^{47,48}$ The lowest bone density loss was among men in the middle drinking categories (between 0.7 and either 1.4 or 1.7 drinks per day), and higher bone density loss was among men with either little or no alcohol consumption and men with the greatest alcohol consumption (at least 1.4 or 1.7 drinks per day). The third study found no linear relationship between continuous alcohol consumption and bone density loss in men. ${ }^{46}$

\section{Alcohol Consumption and Bone Response to Estrogen Replacement}

Two studies assessed the effect of alcohol consumption on bone response to estrogen therapy. One prospective cohort study found that estrogen therapy was independently associated with a 74\% lower risk of hip fracture (RR 0.36 [95\% CI, 0.14-0.90]) among women who consumed 1 drink or more per day, compared with abstainers. ${ }^{49}$ The other was a nested case-control study that defined cases ("good" responders) as women who gained more bone density during 5 years of follow-up than the upper 95th percentile of an untreated group. ${ }^{45}$ After adjustment for multiple potential confounders, alcohol intake was independently associated with being a "good" responder to estrogen therapy.

\section{Alcohol Consumption and Markers of Bone Remodeling}

Markers of Bone Formation. Osteocalcin, a vitamin Kdependent protein synthesized by osteoblasts, is widely used as a clinical marker of bone formation. In 6 experimental studies of heavy drinkers (7-16 drinks per day), the subjects served as their own controls. Osteocalcin levels were measured before and after periods of abstinence ranging from 7 days to 2 years. ${ }^{8,50-54}$ All studies found that osteocalcin increased significantly after abstinence.

Two additional experimental studies found consistent results after administering alcohol to healthy male adults. ${ }^{55,56}$ The doses of alcohol varied from 1.8 drinks given over 45 minutes ${ }^{55}$ to 4 drinks administered daily for 3 weeks. ${ }^{56}$ Both studies found a significant decrease in osteocalcin levels during alcohol administration.

Three of the abstinence studies also examined changes in carboxy-terminal propeptide of type I procollagen, ${ }^{8,52,54} \mathrm{a}$ protein representing synthesis of type-1 collagen. All found a significant increase in carboxy-terminal propeptide of type I procollagen during abstinence.

Markers of Bone Resorption. Hydroxyproline, a modified amino acid that is released during the breakdown of collagen, was measured in 3 studies of heavy drinkers. During abstinence from alcohol, 1 study found a significant increase in urinary hydroxyproline, ${ }^{54}$ and 2 studies found no significant change. ${ }^{8,53}$ 
Table 1 Studies of the Association between Alcohol Consumption and Risk of Hip Fracture

\begin{tabular}{|c|c|c|c|c|}
\hline Study, year & Study Design & Sample Characteristics & $\begin{array}{l}\text { Study } \\
\text { Quality }\end{array}$ & $\begin{array}{l}\text { Duration of Follow- } \\
\text { up }\end{array}$ \\
\hline Felson, 1988 (34) & Framingham Study cohort & 5209 adults, aged 31-95 yrs & fair* & 117,224 person-years \\
\hline Hoidrup (men), 1999 (35) & $\begin{array}{l}\text { Combined data from } \\
\text { three cohort studies }\end{array}$ & 17,868 men, aged $20-93$ yrs & fair* & 434,324 person-years \\
\hline
\end{tabular}

Hoidrup (women), 1999 (35)

Kanis, $2004(36)$

Holbrook, 1988 (37)

Hemenway, 1994

AmJPubHealth (38)

Hernandez-Avila, 1991 (39)

Hansen, 2000 (40)

Mukamal, 2007 (33)

Cumming, 1994 (41)

Baron, 2001 (21)

Grisso, 1994 (31)

La Vecchia, 1991 (42)

Suzuki, 1997 (32)
Combined data from three cohort studies

Combined data from three cohort studies

Rancho Bernando cohort Health Professionals Follow-Up Study

cohort

Nurses Health Study cohort

Iowa Women's Health Study cohort

Cardiovascular Health Study cohort
16,971 adults, aged 25-103 yrs

957 adults, aged 50-79 yrs 49,895 men, aged $40-75$ yrs

84,484 women, aged $29-74$ yrs

34,703 women, aged 55-69 yrs

5865 adults, aged $\geq 65$ yrs fairt§

fair*

\section{fair*tђ}

fair* $† \ddagger$

fair*

482,347 person-years
14 years

270,000 person-years
87,035 person-years

70,380 person-years
Case-control

Case-control

Case-control

Case-control

Case-control
416 adults, aged $65-100$ yrs (209 cases, 207 controls)

4589 postmenopausal women

(1,327 cases, 3,262 controls)

543 black women (144 cases, 399 controls)

1658 women, aged 29-74 yrs (209 cases, 1449 controls)

747 adults, aged $65-89$ yrs (249 cases, 498 controls) fair*

fair*

fair $^{*} \ddagger$

fair*

NA

fair* $\ddagger$
NA

NA

NA

NA

A

A

*Incomplete adjustment for potential confounders (age, body mass index, smoking, dietary calcium, physical activity, and estrogen exposure in women). †alcohol consumption measured at baseline only (prospective studies).

$\ddagger 1$ survey item to measure alcohol consumption or poor explanation of measurement methods

$\S$ fractures ascertained from a single source (prospective studies); II cases not established using hospital records (case-control studies); NA indicates not applicable; BMI indicates body mass index; CVA indicates cerebrovascular accident; DM indicates diabetes mellitus; "Former drinkers" defined as participants who reported abstinence at baseline but at a follow-up visit responded "yes" to either a "change in pattern of drinking in the past 5 years" or "ever regularly consumed $\geq$ drinks daily".

qGaps in categories due to conversion from drinks per week to drinks per day. 


\section{Table 1 Continued}

Timing of Measurement of Alcohol Use
Events

217

Baseline and years 4, $10,20,22,24,26$, and 30

Baseline and between 1 and 3 follow up interviews

Baseline and between
1 and 3 follow up

interviews

Unspecified

Baseline

Baseline

Baseline

Baseline
Age, BMI, smoking, physical activity, original cohort, education, cohort of origin

BMD

Age, sex, BMI, smoking

Age, BMI, smoking, height

Age, BMI, menopausal status, estrogen therapy, calcium use, caffeine exposure

Age, BMI, smoking, physical activity, estrogen therapy, calcium use, caffeine exposure, calories, waist:hip ratio

Age, sex, smoking, weight, height, leisure time physical activity, difficulty arising from a bed or chair, estrogen therapy, thiazide type diuretics, thyroid agents, race, diabetes, hypertension, cardiovascular disease, visual problems, arthritis, previous cancer, weight in early teens, Mini-Mental Status Exam score

Age, sex

Age, BMI, smoking, estrogen therapy

Age, BMI, area of residence

Age, BMI, smoking, estrogen therapy, education, area of residence

BMI, physical activity, coffee and green tea, rural residence, main work activity, sleep disturbance, CVA hemiplegia, DM, milk, fish, sun exposure, immobilization, difficulty bathing independently, type of bed

Unit of Analysis of

Alcohol

Magnitude of Association (95\% CI)

per $7 \mathrm{oz} / \mathrm{wk}$

$<0.1$ drinks/day

$0.1-0.9$ drinks/day

1-1.9 drinks/day

2-3.9 drinks/day

4-5.9 drinks/day

$6-9.9$ drinks/day

$>10$ drinks/day

$<0.1$ drinks/day

$0.1-0.9$ drinks/day

1-1.9 drinks/day

2-3.9 drinks/day

$>4$ drinks/day

0.6 drinks/day

$>1.1$ drinks/day)

$>1.7$ drinks/day

$>2.3$ drinks/day

per 0.9 drinks/day

0 drinks/day

0-1.1 drinks/day

1.1-2.1 drinks/day

$>2.1$ drinks/day

0 drinks/day

0-0.4 drinks/day

$0.4-1.1$ drinks/day

1.1-1.8 drinks/day

$\geq 1.8$ drinks/day

0 drinks/day

$<0.3$ drinks/day

$\geq 0.3$ drinks/day

0 drinks/day

former drinkers

$<0.14$ drinks/day

$0.14-0.86$ drinks/day

1-1.86 drinks/day

$\geq 2$ drinks/day

0 drinks/day

$<1$ drinks/day

$\geq 1$ drinks/day

nondrinkers

drinkers

$<0.2$ drinks/day

$0.2-0.4$ drinks/day

$>0.4$ drinks/day

$0-0.1$ drinks/day

$0.1-0.9$ drinks/day

$\geq 1$ drinks/day

0 drinks/day

$<2$ drinks/day

2-3 drinks/day

$>3$ drinks/day

0 drinks/day

$<1.9$ drinks/day

$\geq 1.9$ drinks/day
Odds Ratio: 1.28 (1.051.56)

Relative Risk: 1.00

0.89 (0.58-1.38)

$0.84(0.54-1.30)$

$0.84(0.54-1.32)$

$1.74(1.06-2.89)$

$1.84(1.00-3.41)$

5.28 (2.60-10.70)

Relative Risk: 1.00

$0.89(0.71-1.12)$

$1.01(0.77-1.33)$

$1.32(0.92-1.87)$

1.01 (0.37-2.75)

Relative Risk: 1.00

$1.70(1.20-2.42$

$2.05(1.35-3.11)$

2.39 (1.39-4.09)

Relative Risk: 1.00

Relative Risk: 1.00

$1.06(0.58-1.93)$

$0.95(0.42-2.17)$

0.91 (0.38-2.17)

Relative Risk: 1.00

0.94 (0.35-2.68)

1.99 (0.97-4.07)

$1.15(0.51-2.61)$

$2.33(1.18-4.57)$

Relative Risk: 1.00

$0.92(0.68-1.24)$

0.79 (0.57-1.10)

Hazard Ratio 1.00

$0.84(0.50-1.43)$

$0.77(0.61-0.98)$

$0.83(0.61-1.12)$

$0.82(0.53-1.26)$

$1.20(0.74-1.95)$

Odds Ratio: 1.00

$0.70(0.50-1.20)$

$0.60(0.30-1.30)$

Odds Ratio: 1.00

$0.70(0.60-0.82)$

$0.72(0.59-0.88)$

$0.70(0.56-0.87)$

0.69 (0.53-0.90)

Odds Ratio: 1.00

$1.3(0.6-2.9)$

$2.2(0.9-5.7)$

Relative Risk: 1.00

0.7 (0.5-1.1)

$1.2(0.8-1.8)$

$1.0(0.5-1.8)$

Odds Ratio: 1.00

$0.51(0.29-0.89)$

$0.77(0.33-1.79)$ 


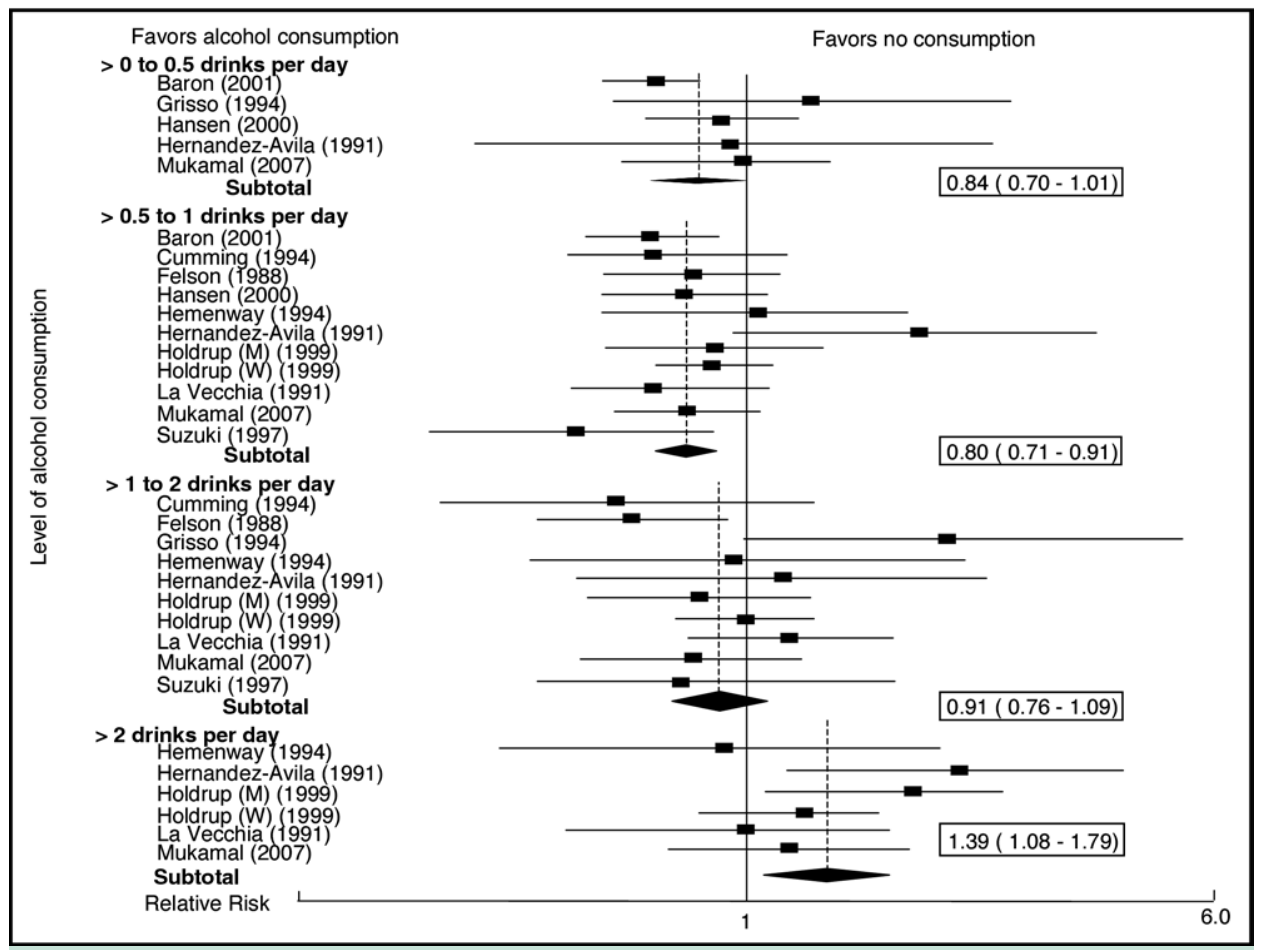

Figure 2 Association between alcohol consumption and hip fracture risk. Reference exposure is zero drinks per day. Size of data marker represents sample size. Horizontal lines denote $95 \%$ confidence intervals.

Table 2 Studies of the Association between Alcohol Consumption and Bone Mineral Density

\begin{tabular}{|c|c|c|c|c|c|}
\hline Study, Year & Sample Characteristics & $\begin{array}{l}\text { Study } \\
\text { Quality }\end{array}$ & $\begin{array}{l}\text { Duration of } \\
\text { Follow-up }\end{array}$ & $\begin{array}{l}\text { Measurement of } \\
\text { Alcohol Consumption }\end{array}$ & Outcome Measure \\
\hline Mukamal, 2007 (33) & 5865 adults, aged $\geq 65$ yrs & fair* & 12 years & $\begin{array}{l}\text { Baseline and annually } \\
\text { for } 9 \text { or } 10 \text { years }\end{array}$ & femoral neck BMD \\
\hline
\end{tabular}

Holbrook et al. (Rancho Bernando), 1993

(13)

Felson et al.

(Framingham Study),

1995 (12)

Feskanich et al.

(Nurses' Health

Study), 1999 (16)

Holbrook et al. (Rancho

Bernando), 1993

(13)
267 women, mean age 60 yrs

fair*

12 yrs

Baseline and year 12

femoral neck BMD

1,154 adults, aged 68-96 yrs

fair*

20 yrs

(data shown for women)

188 women, aged 50-74

182 men, mean age 59 yrs

fair*

14 yrs

fair*

$12 \mathrm{yrs}$

20 yrs
1,154 adults, aged 68-96 yrs

(data shown for men)

fair*

(Framingham Study)

1995 (12) 


\section{DISCUSSION}

Our analysis demonstrates a J-shaped relationship between alcohol consumption and hip fracture risk, with persons consuming up to 1 drink per day having the lowest risk of hip fracture. In contrast, most data on alcohol consumption and bone density suggest a linear association between greater alcohol consumption and both higher bone density and lower bone density loss over time. Studies evaluating hip fracture risk included subjects with greater alcohol consumption than studies evaluating bone density, which may explain why the association between alcohol consumption and hip fracture was $\mathrm{J}$-shaped rather than linear. Because studies of alcohol consumption and bone density included few heavier drinkers, current evidence is insufficient to determine a precise amount of alcohol consumption that is associated with higher bone density.

Compared with abstainers, moderate drinkers had lower hip fracture risk and heavier drinkers had higher hip fracture risk. However, important biases may have influenced these results. It is likely that falls contributed to the observed increase in hip fracture risk among heavier drinkers. Further, most categories of nondrinkers included both lifetime abstainers and former drinkers. If former drinkers stopped for health reasons, this may partially explain the higher hip fracture risk among nondrinkers.
In contrast with the J-shaped association between alcohol consumption and hip fracture risk, pooled data suggest a linear relationship between alcohol consumption and bone density. These data were derived from studies mainly of individuals consuming less than 2 drinks per day. Because these studies may have been underpowered to demonstrate changes in bone density at greater alcohol consumption levels, the observed linear association may not fully describe this relationship. In addition, the increase in bone density associated with each additional drink per day was small in magnitude and of uncertain clinical significance.

The exact mechanism by which alcohol influences bone density is not clear. Putative biological mechanisms for a beneficial effect of alcohol on bone density include increases in the concentration of serum estradiol ${ }^{57,58}$ and liver estrogen receptors. ${ }^{59}$ However, as has been suggested regarding other beneficial effects of moderate alcohol consumption, the observed benefit may reflect confounding by unmeasured healthy behaviors. ${ }^{60,61}$ An important limitation of the existing literature, and the reason most studies were rated "fair," is that few studies sufficiently adjusted for major potential confounders, and none included markers of socioeconomic status. Although our finding that alcohol consumption augments the benefits of estrogen therapy is based on a small number of studies, it is consistent with research suggesting that alcohol ingestion leads to elevations in circulating estradiol levels in women taking

\section{Table 2 Continued}

\begin{tabular}{|c|c|c|c|c|}
\hline Potential Confounders Adjusted for in Analysis & $\begin{array}{l}\text { Statistical Measure } \\
\text { of Association }\end{array}$ & $\begin{array}{l}\text { Unit of Analysis of } \\
\text { Alcohol }\end{array}$ & $\begin{array}{l}\text { BMD } \\
(\mathrm{g} / \mathrm{cm} 2)\end{array}$ & $p$ Value \\
\hline $\begin{array}{l}\text { Age, sex, smoking, weight, height, leisure time physical activity, difficulty } \\
\text { arising from a bed or chair, estrogen therapy, thiazide type diuretics, } \\
\text { thyroid agents, race, diabetes, hypertension, cardiovascular disease, } \\
\text { visual problems, arthritis, previous cancer, weight in early teens, Mini- } \\
\text { Mental Status Exam score }\end{array}$ & F-tests & $\begin{array}{l}0 \text { drinks/day } \dagger \\
\text { former drinkers } \\
<0.14 \text { drinks/day } \\
0.14-0.86 \text { drinks/day } \\
1-1.86 \text { drinks/day } \\
\geq 2 \text { drinks/day }\end{array}$ & $\begin{array}{l}0.69 \\
0.72 \\
0.69 \\
0.70 \\
0.73 \\
0.74\end{array}$ & $<0.001$ \\
\hline Age, smoking, BMI, exercise and estrogen therapy & $\chi^{2}$ & $\begin{array}{l}0 \text { drinks/day } \\
<0.5 \text { drinks/day } \\
0.5-1.2 \text { drinks/day } \\
>1.2 \text { drinks/day }\end{array}$ & $\begin{array}{l}0.64 \\
0.63 \\
0.62 \\
0.64\end{array}$ & NS \\
\hline $\begin{array}{l}\text { Age, smoking, weight, height, age at menopause, durat ion of estrogen } \\
\text { use }\end{array}$ & $\chi^{2}$ & $\begin{array}{l}<0.2 \text { drinks/day } \dagger \\
0.2-0.4 \text { drinks/day } \\
0.7-1.4 \text { drinks/day } \\
\geq 1.7 \text { drinks/day }\end{array}$ & $\begin{array}{l}0.71 \\
0.70 \\
0.71 \\
0.74\end{array}$ & NS \\
\hline Age, smoking, BMI, estrogen therapy, age at menopause & $\chi^{2}$ & $\begin{array}{l}<0.3 \text { drinks/day } \\
0.3-0.8 \text { drinks/day } \\
>0.8 \text { drinks/day }\end{array}$ & $\begin{array}{l}0.65 \\
0.67 \\
0.67\end{array}$ & NS \\
\hline Age, smoking, BMI, exercise & $\chi^{2}$ & $\begin{array}{l}0 \text { drinks/day } \\
<0.9 \text { drinks/day } \\
0.9-1.8 \text { drinks/day } \\
>1.8 \text { drinks/day }\end{array}$ & $\begin{array}{l}0.68 \\
0.72 \\
0.78 \\
0.75\end{array}$ & $\begin{array}{l}<0.01 \\
\text { for } \\
\text { trend }\end{array}$ \\
\hline Age, smoking, weight, height & $\chi^{2}$ & $\begin{array}{l}<0.2 \text { drinks/day } \\
0.2-0.4 \text { drinks/day } \\
0.7-1.4 \text { drinks/day } \\
1.7-2.9 \text { drinks/day } \\
\geq 3 \text { drinks/day }\end{array}$ & $\begin{array}{l}0.86 \\
0.86 \\
0.88 \\
0.85 \\
0.88\end{array}$ & NS \\
\hline
\end{tabular}




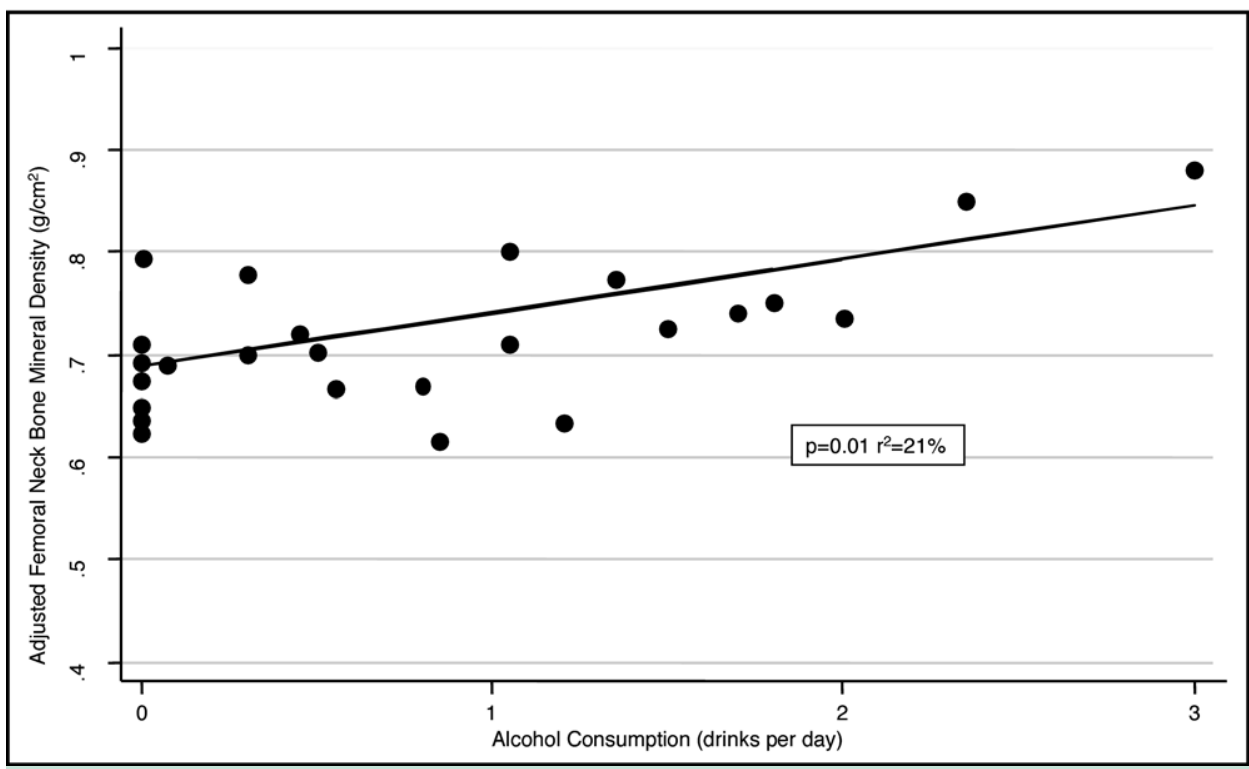

Figure 3 Association between alcohol consumption and adjusted femoral neck bone mineral density. Adjustment for confounders is variable. Study adjusting for the fewest covariates controlled for age, smoking, weight, and height. Study adjusting for the most covariates also controlled for leisure time physical activity, difficulty arising from a bed or chair, estrogen therapy, thiazide-type diuretics, thyroid agents, race, diabetes, hypertension, cardiovascular disease, visual problems, arthritis, previous cancer, weight in early teens, and Mini-Mental Status Exam score.

Table 3 Studies of the Association between Alcohol Consumption and Bone Mineral Density Loss Over Time

\begin{tabular}{|c|c|c|c|c|c|}
\hline Study, Year & Sample Characteristics & $\begin{array}{l}\text { Study } \\
\text { Quality }\end{array}$ & $\begin{array}{l}\text { Duration of } \\
\text { Follow-up }\end{array}$ & $\begin{array}{l}\text { Measurement of Alcohol } \\
\text { Consumption }\end{array}$ & Outcome (Unit) \\
\hline \multicolumn{6}{|c|}{ BMD loss at the femoral neck among women } \\
\hline Dennison et al. 1999 (46) & 143 women, aged $60-75$ yrs & fair $^{*} \ddagger$ & 4 yrs & Baseline and year 4 & $\begin{array}{l}\text { Annual BMD loss at the } \\
\text { femoral neck }\end{array}$ \\
\hline $\begin{array}{l}\text { Rejnmark et al. (Danish Osteoporosis } \\
\text { Prevention Study), } 2004 \text { (45) }\end{array}$ & 932 women, mean age 49 yrs & fair* $^{*} \ddagger$ & 5 yrs & Baseline & $\begin{array}{l}\text { BMD loss at the } \\
\text { femoral neck ( } \mathrm{g} / \\
\mathrm{cm} 2)\end{array}$ \\
\hline
\end{tabular}

Hannan et al. (Framingham 0steoporosis

Study), 2000 (48)

BMD loss at the femoral neck among men

Burger et al. (Rotterdam Study), 1998 (47)

Hannan et al. (Framingham 0steoporosis

Study), 2000 (48)

Dennison et al. 1999 (46)
486 women, aged 67-90 yrs fair*

1856 men, mean age 67 yrs fairtђ median 1.9 yrs Baseline

278 men, aged 67-90 yrs

fair $^{*} \dagger \ddagger \quad 4$ yrs

Baseline

173 men, aged 60-75 yrs fair $\quad 4$ yrs

Baseline and year 4

BMD loss at the femoral neck (\%/yr)

*Incomplete adjustment for potential confounders (age, body mass index, smoking, dietary calcium, physical activity, and estrogen exposure in women). falcohol consumption measured at baseline only.

$\ddagger 1$ survey item to measure alcohol consumption or poor explanation of measurement methods. BMD indicated bone mineral density; BMI indicates body mass index; NS indicates not significant; NR indicates not reported. 
estrogen replacement therapy. ${ }^{62-64}$ Because of this association, studies that did not control for estrogen exposure may be particularly vulnerable to bias.

Most studies of bone density loss in women demonstrated an inverse linear relationship between alcohol consumption and bone density loss over time, whereas most studies in men reported a J-shaped relationship. Although sex differences in the effect of alcohol consumption on bone density have been suggested, ${ }^{65}$ observed differences might be explained by differences in alcohol exposure. Studies of bone density loss over time frequently combined moderate and heavy drinkers in a single category, making the greatest drinking category heterogeneous. For example, if the population of women categorized as consuming more than 1.4 drinks per day consumed less alcohol than men in the same drinking category, data from men and women would suggest different patterns of association between alcohol consumption and bone density due partly to misclassification. Further research is needed to characterize sex differences in the effect of alcohol on bone density loss over time.

Data from experimental studies indicate that osteocalcin increases after abstinence and decreases after alcohol administration. These results suggest a reversible suppression of bone formation when administered rapidly or in large doses, and are consistent with prior research. ${ }^{66,67}$ The effect of long-term alcohol consumption on bone remodeling likely involves a complex uncoupling of formation and resorption. ${ }^{68}$ Heavy alcohol consumption may have a direct acute negative effect on osteoblasts, but positive effects of alcohol on bone density may be due to indirect long-term hormonal effects. ${ }^{69}$ The precise effects of moderate alcohol consumption on bone metabolism are still unknown.

A key limitation of many original studies in this review was the method and timing of alcohol consumption measurement, a weakness that has been noted by other reviews and meta-analyses of alcohol consumption. ${ }^{29,70,71}$ Studies that measured alcohol consumption only at baseline are vulnerable to misclassification if exposure to alcohol changed before the outcome was measured. In addition, collecting data on alcohol consumption by self-report using simple surveys may lead to underreporting, particularly among heavy drinkers. ${ }^{72,73}$ Despite this potential reporting bias, the rank order of alcohol consumption reported by individual studies is unlikely to be affected.

Because most included studies were observational, these results must be interpreted with caution. Although many benefits, including decreased mortality, ${ }^{74}$ have been attributed to moderate alcohol consumption, the appropriateness

Table 3 Continued

\begin{tabular}{|c|c|c|c|c|c|}
\hline $\begin{array}{l}\text { Potential Confounders Adjusted for in } \\
\text { Analysis }\end{array}$ & $\begin{array}{l}\text { Statistical Measure } \\
\text { of Association }\end{array}$ & $\begin{array}{l}\text { Unit of Analysis of } \\
\text { Alcohol }\end{array}$ & $\begin{array}{l}\text { BMD } \\
\text { Loss }\end{array}$ & $\begin{array}{l}\text { Magnitude of } \\
\text { Association }\end{array}$ & $p$ Value \\
\hline $\begin{array}{l}\text { Age, smoking, BMI, change in BMI, activity, } \\
\text { calcium intake, osteoarthritis grade }\end{array}$ & Beta-coefficient & per 0.1 drinks/day & NA & $(-0.07)$ & 0.007 \\
\hline $\begin{array}{l}\text { Age, smoking, weight, waist to hip ratio, } \\
\text { time since menopause, est rogen therapy, } \\
\text { total energy, calcium, vitamin D intake, } \\
\text { metabolic markers of metabolism }\end{array}$ & Beta-coefficient & per gram of alcohol/day & NA & $(-0.048)$ & $p<0.001$ \\
\hline $\begin{array}{l}\text { Age, smoking, height, weight, weight } \\
\text { change, BMD, activity, activity change, } \\
\text { menopausal status, estrogen therapy, } \\
\text { socioeconomic status, consuming a } \\
\text { weight-reducing diet, osteoarthritis }\end{array}$ & Beta-coefficient & $\begin{array}{l}\text { per quartile (medians) } \\
0 \text { drinks/day } \\
0.2 \text { drinks/day } \\
0.5 \text { drinks/day } \\
1.0 \text { drinks/day }\end{array}$ & NA & $(-0.0893)$ & 0.002 \\
\hline $\begin{array}{l}\text { Age, smoking, BMI, calcium and energy } \\
\text { intake, lower limb disability }\end{array}$ & Beta-coefficient & $\begin{array}{l}0 \text { drinks/d } \\
0-<0.7 \text { drinks/day } \\
0.7-<1.4 \text { drinks/day } \\
>=1.4 \text { drinks/day }\end{array}$ & $\begin{array}{l}0.0056 \\
0.0042 \\
0.0051 \\
0.0027\end{array}$ & NR & NS \\
\hline $\begin{array}{l}\text { Age, smoking, weight, weight change, } \\
\text { height, estrogen therapy }\end{array}$ & Least squares mean & $\begin{array}{l}0-<0.2 \text { drinks/day } \\
0.2-0.7 \text { drinks/day } \\
>0.7-1.7 \text { drinks/day } \\
>1.7 \text { drinks/day }\end{array}$ & $\begin{array}{l}2.39 \\
2.05 \\
2.28 \\
3.09\end{array}$ & NR & NS \\
\hline $\begin{array}{l}\text { Age, smoking, BMI, calcium and energy } \\
\text { intake, lower limb disability }\end{array}$ & Beta-coefficient & $\begin{array}{l}0 \text { drinks/day } \\
0-<0.7 \text { drinks/day } \\
0.7-<1.4 \text { drinks/day } \\
>=1.4 \text { drinks/day }\end{array}$ & $\begin{array}{l}0.0057 \\
0.0025 \\
0.0012 \\
0.0048\end{array}$ & NR & NS \\
\hline Age, smoking, weight, weight change, height & Least squares mean & $\begin{array}{l}0-<0.2 \text { drinks/day } \\
0.2-0.7 \text { drinks/day } \\
>0.7-1.7 \text { drinks/day } \\
>1.7 \text { drinks/day }\end{array}$ & $\begin{array}{l}2.68 \\
2.66 \\
2.57 \\
3.27\end{array}$ & NR & NS \\
\hline $\begin{array}{l}\text { Age, smoking, BMI, change in BMI, activity, } \\
\text { calcium intake, osteoarthritis grade }\end{array}$ & Beta-coefficient & per 0.1 drinks/day & NA & NR & NS \\
\hline
\end{tabular}


of using nondrinkers as a reference group has been questioned. ${ }^{75,76}$ To expand our understanding of the effects of alcohol on bone density, rigorous prospective studies are needed that carefully measure potential confounders. Because bone density reflects the cumulative effects of numerous factors on bone metabolism over long periods of time, future studies should adjust for baseline bone density.

\section{CONCLUSIONS}

Current best evidence on the effect of alcohol on bone density suggests that compared with abstinence, consumption of up to
1 drink per day is associated with a decreased risk of osteoporotic hip fracture. Further, most evidence supports a beneficial effect of moderate alcohol consumption on bone density. However, evidence is insufficient to determine relative associations between alcohol consumption and bone density in moderate compared with heavy drinkers.

\section{ACKNOWLEDGMENTS}

The authors thank Racheline G. Habousha, MSLS, AHIP, for assistance with the literature search and David Hamerman, MD, for guidance with article selection criteria.

\section{APPENDIX}

Medical Subject Headings and Text Words Used in Literature Search

\begin{tabular}{lll}
\hline Concept & MeSH Terms & Text Words \\
\hline Alcohol Consumption & $\begin{array}{l}\text { Alcohol-related disorders } \\
\text { Alcoholism }\end{array}$ & Alcohol, alcoholic, alcoholism, beer, wine, liquor \\
& $\begin{array}{l}\text { Alcoholic beverages } \\
\text { Alcohol drinking } \\
\text { Bone Mineral Density }\end{array}$ & \\
& $\begin{array}{l}\text { Osteoporosis } \\
\text { Postmenopausal osteoporosis } \\
\text { Bone density Metabolic bone diseases } \\
\text { Pathologic bone demineralization }\end{array}$ & Osteoporosis, osteopenia, bone mineral density, BMD, bone resorption \\
Osteoporotic Fractures & $\begin{array}{l}\text { Fractures } \\
\text { Spontaneous fractures } \\
\text { Hip fracture } \\
\text { Spinal fractures } \\
\text { Wrist injuries } \\
\text { Bone resorption }\end{array}$ & $\begin{array}{l}\text { Compression fracture, fragility fracture, atraumatic fracture } \\
\text { Metabolism }\end{array}$ \\
& $\begin{array}{l}\text { Telopeptide, n-telopeptide, c-telopeptide, osteocalcin, bone-Gla } \\
\text { protein, BGP, bone and alkaline phosphatase, deoxypyridinoline, } \\
\text { hydroxyproline, tartrate-resistant acid phosphatase, TRACP, bone and } \\
\text { sialoprotein, hydroxylysine }\end{array}$ \\
\hline
\end{tabular}

$B M D$, Bone mineral density; $B G P$, beta-glycerophosphatase; TRACP, tartrate-resistant acid phosphatase.

\section{References}

1. Advocacy News and Updates. Washington DC. National Osteoporosis Foundation. Available at: http://www.nof.org/advocacy/prevalence/ index.htm. Accessed June 28, 2007.

2. Osteoporosis Disease Facts. Washington DC. National Osteoporosis Foundation. Available at: http://www.nof.org/osteoporosis/diseasefacts.htm. Accessed June 28, 2007.

3. Spencer H, Rubio N, Rubio E, et al. Chronic alcoholism. Frequently overlooked cause of osteoporosis in men. Am J Med. 1986;80:393397.

4. Bikle DD, Genant HK, Cann C, et al. Bone disease in alcohol abuse. Ann Intern Med. 1985;103:42-48.

5. Lalor BC, France MW, Powell D, et al. Bone and mineral metabolism and chronic alcohol abuse. $Q J$ Med. 1986;59:497-511.

6. Feitelberg S, Epstein S, Ismail F, D'Amanda C. Deranged bone mineral metabolism in chronic alcoholism. Metab Clin Exp. 1987;36:322326.

7. Chon KS, Sartoris DJ, Brown SA, Clopton P. Alcoholism-associated spinal and femoral bone loss in abstinent male alcoholics, as measured by dual X-ray absorptiometry. Skeletal Radiol. 1992;21: 431-436.

8. Laitinen K, Karkkainen M, Lalla M, et al. Is alcohol an osteoporosisinducing agent for young and middle-aged women? Metab Clin Exp. 1993;42:875-881.
9. Williams FM, Cherkas LF, Spector TD, MacGregor AJ. The effect of moderate alcohol consumption on bone mineral density: a study of female twins. Ann Rheum Dis. 2005;64:309-310.

10. Nguyen TV, Kelly PJ, Sambrook PN, et al. Lifestyle factors and bone density in the elderly: implications for osteoporosis prevention. $J$ Bone Miner Res. 1994;9:1339-1346.

11. Orwoll ES, Bauer DC, Vogt TM, Fox KM. Axial bone mass in older women. Study of Osteoporotic Fractures Research Group. Ann Intern Med. 1996;124:187-196.

12. Felson DT, Zhang Y, Hannan MT, et al. Alcohol intake and bone mineral density in elderly men and women. The Framingham Study. Am J Epidemiol. 1995;142:485-492.

13. Holbrook TL, Barrett-Connor E. A prospective study of alcohol consumption and bone mineral density. BMJ. 1993;306:1506-1509.

14. May H, Murphy S, Khaw KT. Alcohol consumption and bone mineral density in older men. Gerontology. 1995;41:152-158.

15. Cauley JA, Fullman RL, Stone KL, et al. Factors associated with the lumbar spine and proximal femur bone mineral density in older men. Osteoporos Int. 2005;16:1525-1537.

16. Feskanich D, Korrick SA, Greenspan SL, et al. Moderate alcohol consumption and bone density among postmenopausal women. $J$ Womens Health. 1999;8:65-73.

17. Hansen MA, Overgaard K, Riis BJ, Christiansen C. Potential risk factors for development of postmenopausal osteoporosis--examined over a 12-year period. Osteoporos Int. 1991;1:95-102. 
18. Laitinen K, Valimaki M, Keto P. Bone mineral density measured by dual-energy X-ray absorptiometry in healthy Finnish women. Calcif Tissue Int. 1991;48:224-231.

19. NIH Consensus Development Panel on Osteoporosis Prevention, Diagnosis, and Therapy. Osteoporosis prevention, diagnosis, and therapy. JAMA. 2001;285:785-795.

20. Harris RP, Helfand M, Woolf SH, et al. Current methods of the U.S. Preventive Services Task Force: a review of the process. Am J Prev Med. 2001;20(3 Suppl):21-35.

21. Baron JA, Farahmand BY, Weiderpass E, et al. Cigarette smoking, alcohol consumption, and risk of hip fracture in women.Arch Intern Med. 2001;161:983-988.

22. Macdonald HM, New SA, Golden MH, et al. Nutritional associations with bone loss during the menopausal transition: evidence of a beneficial effect of calcium, alcohol, and fruit and vegetable nutrients and of a detrimental effect of fatty acids. Am J Clin Nutr. 2004;79:155-165.

23. Description for standard drinks chart. National Institute on Alcohol Abuse and Alcoholism, U.S. Dept of Health and Human Services; 2005. Available at: http://pubs.niaaa.nih.gov/publications/Practitioner/ PocketGuide/pocket_guide2.htm. Accessed June 28, 2007.

24. Alcohol. Better Health Channel. Melbourne Australia; 1999. Available at: www.betterhealth.vic.gov.au/BHCV2/bhcarticles.nsf/pages/Alcohol. Accessed June 28, 2007.

25. Difficulties in measuring drinking levels. DrugsAlcohol.info, Health Promotion Agency. Available at: http://www.drugsalcohol.info/alcohol/default.asp?artId = 45. Accessed June 28, 2007.

26. DerSimonian R, Laird N. Meta-analysis in clinical trials. Control Clin Trials. 1986;7:177-188.

27. Greenland S, Longnecker MP. Methods for trend estimation from summarized dose-response data, with applications to meta-analysis. Am J Epidemiol. 1992;135:1301-1309.

28. Follmann D, Elliott P, Suh I, Cutler J. Variance imputation for overviews of clinical trials with continuous response. J Clin Epidemiol. 1992;45:769-773.

29. Koppes LL, Dekker JM, Hendriks HF, et al. Moderate alcohol consumption lowers the risk of type 2 diabetes: a meta-analysis of prospective observational studies. Diabetes Care. 2005;28:719-725.

30. Egger M, Davey Smith G, Schneider M, Minder C. Bias in metaanalysis detected by a simple, graphical test. BMJ. 1997;315:629-634.

31. Grisso JA, Kelsey JL, Strom BL, et al. Risk factors for hip fracture in black women. The Northeast Hip Fracture Study Group. N Engl J Med. 1994;330:1555-1559.

32. Suzuki T, Yoshida H, Hashimoto T, et al. Case-control study of risk factors for hip fractures in the Japanese elderly by a Mediterranean Osteoporosis Study (MEDOS) questionnaire. Bone. 1997;21:461-467.

33. Mukamal KJ, Robbins JA, Cauley JA, et al. Alcohol consumption, bone density, and hip fracture among older adults: the cardiovascular health study. Osteoporos Int. 2007;18:593-602.

34. Felson DT, Kiel DP, Anderson JJ, Kannel WB. Alcohol consumption and hip fractures: the Framingham Study. Am J Epidemiol. 1988;128: 1102-1110.

35. Hoidrup S, Gronbaek M, Gottschau A, et al. Alcohol intake, beverage preference, and risk of hip fracture in men and women. Copenhagen Centre for Prospective Population Studies. Am J Epidemiol. 1999;149: 993-1001.

36. Kanis JA, Johansson H, Johnell O, et al. Alcohol intake as a risk factor for fracture. Osteoporos Int. 2004;16:799-804.

37. Holbrook TL, Barrett-Connor E, Wingard DL. Dietary calcium and risk of hip fracture: 14-year prospective population study. Lancet. 1988;2:1046-1049.

38. Hemenway D, Azrael DR, Rimm EB, et al. Risk factors for hip fracture in U.S. men aged 40 through 75 years. Am J Public Health. 1994;84:1843-1845.

39. Hernandez-Avila M, Colditz GA, Stampfer MJ, et al. Caffeine, moderate alcohol intake, and risk of fractures of the hip and forearm in middle-aged women. Am J Clin Nutr. 1991;54:157-163.
40. Hansen SA, Folsom AR, Kushi LH, Sellers TA. Association of fractures with caffeine and alcohol in postmenopausal women: the Iowa Women's Health Study. Public Health Nutr. 2000;3:253-261.

41. Cumming RG, Klineberg RJ. Case-control study of risk factors for hip fractures in the elderly. Am J Epidemiol. 1994;139:493-503.

42. La Vecchia C, Negri E, Levi F, Baron JA. Cigarette smoking, body mass and other risk factors for fractures of the hip in women. Int $J$ Epidemiol. 1991;20:671-677.

43. Hemenway D, Azrael DR, Rimm EB, et al. Risk factors for wrist fracture: effect of age, cigarettes, alcohol, body height, relative weight, and handedness on the risk for distal forearm fractures in men. Am J Epidemiol. 1994;140:361-367.

44. Samelson EJ, Hannan MT, Zhang Y, et al. Incidence and risk factors for vertebral fracture in women and men: 25-year follow-up results from the populations-based Framingham study. J Bone Miner Res. 2006;21:1207-1214.

45. Rejnmark L, Vestergaard P, Tofteng CL, et al. Response rates to oestrogen treatment in perimenopausal women: 5-year data from the Danish Osteoporosis Prevention Study (DOPS). Maturitas. 2004;48: 307-320.

46. Dennison E, Eastell R, Fall CH, et al. Determinants of bone loss in elderly men and women: a prospective population-based study.Osteoporos Int. 1999;10:384-391.

47. Burger H, de Laet CE, van Daele PL, et al. Risk factors for increased bone loss in an elderly population: the Rotterdam Study. Am J Epidemiol. 1998; 147:871-879.

48. Hannan MT, Felson DT, Dawson-Hughes B, et al. Risk factors for longitudinal bone loss in elderly men and women: the Framingham Osteoporosis Study. J Bone Min Res. 2000;15:710-720.

49. Hoidrup S, Gronbaek M, Pedersen AT, Lauritzen JB, Gottschau A, Schroll M. Hormone replacement therapy and hip fracture risk: effect modification by tobacco smoking, alcohol intake, physical activity, and body mass index. Am J Epidemiol. 1999;150:1085-1093.

50. Peris P, Pares A, Guanabens N, et al. Bone mass improves in alcoholics after 2 years of abstinence. J Bone Miner Res. 1994;9:16071612.

51. Gonzalez-Calvin JL, Garcia-Sanchez A, Bellot V, et al. Mineral metabolism, osteoblastic function and bone mass in chronic alcoholism. Alcohol Alcohol. 1993;28:571-579.

52. Nyquist F, Ljunghall S, Berglund M, Obrant K. Biochemical markers of bone metabolism after short and long time ethanol withdrawal in alcoholics. Bone. 1996;19:51-54.

53. Pepersack T, Fuss M, Otero J, et al. Longitudinal study of bone metabolism after ethanol withdrawal in alcoholic patients. $J$ Bone Miner Res. 1992;7:383.

54. Laitinen K, Lamberg-Allardt C, Tunninen R, et al. Bone mineral density and abstention-induced changes in bone and mineral metabolism in noncirrhotic male alcoholics.Am J Med. 1992;93:642-650.

55. Garcia-Sanchez A, Gonzalez-Calvin JL, Diez-Ruiz A, et al. Effect of acute alcohol ingestion on mineral metabolism and osteoblastic function. Alcohol Alcohol. 1995;30:449-453.

56. Laitinen K, Lamberg-Allardt C, Tunninen R, et al. Effects of 3 weeks' moderate alcohol intake on bone and mineral metabolism in normal men. Bone Miner. 1991;13:139-151.

57. Gavaler JS, Van Thiel DH. The association between moderate alcoholic beverage consumption and serum estradiol and testosterone levels in normal post-menopausal women: relationship to the literature. Alcohol Clin Exp Res. 1992;16:87.

58. Gavaler JS. Oral hormone replacement therapy: factors that influence the estradiol concentrations achieved in a multiracial study population. J Clin Pharmacol. 2002;42:137-144.

59. Chung KW. Effects of chronic ethanol intake on aromatization of androgens and concentration of estrogen and androgen receptors in rat liver. Toxicology. 1990;62:285-295.

60. Rimm EB. Alcohol consumption and coronary heart disease: good habits may be more important than just good wine. Am J Epidemiol. 1996;143:1094-1098. 
61. Nielsen NR, Schnohr P, Jensen G, Gronbaek M. Is the relationship between type of alcohol and mortality influenced by socio-economic status? J Intern Med. 2004;255:280-288.

62. Ginsburg ES, Mello NK, Mendelson JH, et al. Effects of alcohol ingestion on estrogens in postmenopausal women. JAMA. 1996;276: 1747-1751.

63. Purohit V. Moderate alcohol consumption and estrogen levels in postmenopausal women: a review. Alcohol Clin Exp Res. 1998;22:994997.

64. Hankinson SE, Willett WC, Manson JE, et al. Alcohol, height, and adiposity in relation to estrogen and prolactin levels in postmenopausal women. J Natl Cancer Inst. 1995;87:1297-1302.

65. Turner RT. Skeletal response to alcohol. Alcohol Clin Exp Res. 2000; 24:1693-1701.

66. Klein RF, Fausti KA, Carlos AS. Ethanol inhibits human osteoblastic cell proliferation. Alcohol Clin Exp Res. 1920;572-578.

67. Chavassieux $P$, Serre $C M$, Vergnaud $P$, et al. In vitro evaluation of dose-effects of ethanol on human osteoblastic cells. Bone Miner. 1993;22:95-103.

68. Chakkalakal DA. Alcohol-induced bone loss and deficient bone repair. Alcohol Clin Exp Res. 2005;29:2077-2090.
69. Sampson HW, Shipley D. Moderate alcohol consumption does not augment bone density in ovariectomized rats. Alcohol Clin Exp Res. 1997;21:1165-1168.

70. Cook RL, Clark DB. Is there an association between alcohol consumption and sexually transmitted diseases? A systematic review. Sex Transm Dis. 2005;32:156-164.

71. Howard AA, Arnsten JH, Gourevitch MN. Effect of alcohol consumption on diabetes mellitus: a systematic review. Ann Intern Med. 2004; 140:211-219.

72. Koppes LL, Twisk JW, Snel J, Kemper HC. Concurrent validity of alcohol consumption measurement in a 'healthy' population; quantityfrequency questionnaire v. dietary history interview. Br J Nutr. 2002; $88: 427-434$.

73. Feunekes GI, van't Veer, van Staveren WA, Kok FJ. Alcohol intake assessment: the sober facts. Am J Epidemiol. 1999;150:105-112.

74. Di Castelnuovo A, Costanzo S, Bagnardi V, et al. Alcohol dosing and total mortality in men and women: an updated meta-analysis of 34 prospective studies. Arch Intern Med. 2006;166:2437-2445.

75. Wannamethee SG, Shaper AG. Lifelong teetotalers, ex-drinkers and drinkers: mortality and the incidence of major coronary heart disease events in middle-aged British men. Int J Epidemiol. 1997;26:523-531.

76. Abdulla S. Is alcohol really good for you? J R Soc Med. 1997;90:651. 